DOI: $10.19195 / 2084-5065.43 .18$

\title{
Społeczne niebezpieczeństwo czynu jako warunek kryminalizacji
}

\author{
JAN KULESZA \\ Katedra Prawa Karnego \\ Uniwersytet Łódzki
}

Podtytuł niniejszego opracowania powinien brzmieć: O kryminogennych skutkach działalności naukowej prof. zw. dra hab. Tomasza Kaczmarka. Dlaczego? Już tłumaczę. Otóż przygotowując niniejszy tekst, próbowałem dotrzeć do pierwszych monograficznych prac Jubilata o tytułach Społeczne niebezpieczeństwo czynu i jego bezprawność jako dwie cechy przestęstwa oraz Materialna istota przestępstwa i jego ustawowe znamiona. Cóż się okazało? Dotrzeć do nich niepodobna. Z wszystkich tomów serii „Prawo. Acta Universitatis Wratislaviensis” akurat tomy 16 i 26 wykazują zadziwiającą zdolność dematerializacji z bibliotecznych regałów, należąc również do nienaruszalnego zbioru, znienawidzonego przez każdego bywalca bibliotek, opatrzonego opisem „Tylko na miejscu”. Jako że jednak obracamy się w kręgu karnistów, nie prestidigitatorów, doświadczenie każe podejrzewać, że tomy te padły łupem łowców wiedzy i mądrości, pozostających pod takim wrażeniem ich zawartości, że rozstać się z nimi nie byli w stanie. Musieli zatem dokonać ich przywłaszczenia (art. $284 \S 2$ k.k., z pewnością nie $\S 3)^{1}$. W ten sposób właśnie te dwa dzieła Jubilata przyczyniły się do wzrostu liczby po-

* Niniejsze opracowanie stanowi skróconą wersję rozdziału monografii pt. Wstęp do teorii kryminalizacji. Studium z zakresu prawa karnego i konstytucyjnego, Łódź 2017 (w druku).

1 Pomijając w tym miejscu rozważania na temat ewentualnych podstaw uchylenia przestępności takiego czynu, czy to ze względu na stan wyższej konieczności wyłączający bezprawność (art. $26 \S 1$ k.k., prawo własności poświęcone dla ratowania przed bezpośrednim niebezpieczeństwem pozostawania w stanie niewiedzy), czy niemożność postawienia zarzutu winy ze względu na anormalną sytuację motywacyjną i niemożność dania posłuchu prawu (poczucie konieczności posiadania dzieła Jubilata nie do opanowania), o ile przyjmujemy otwartą możliwość nieprzypisywania winy przez sędziego (normatywną teorię winy w czystej postaci), czy wreszcie obiektywną nieprzypisywalność skutku, o kontratypie pozaustawowym badań naukowych już nie wspominając. Możliwości są, jak widać, liczne. 
pełnionych przestępstw, stanowiąc ów czynnik kryminogenny wśród karnistów-filozofów ${ }^{2}$. Trudno się im dziwić. Już te pierwsze prace Jubilata cechuje tak wielka wszechstronność i przenikliwość analizy oraz jasność wywodu, prowadząca czytelnika do wniosków, z którymi nie sposób się nie zgodzić, że pozostają one wciąż w obiegu naukowym, stanowiąc nie tylko fundament nauki o materialnym elemencie przestępstwa w polskiej doktrynie karnistycznej, lecz także inspirację dla dalszych analiz, czego dowodem jest poniższy tekst ${ }^{3}$.

Zachowanie człowieka mające być poddane kryminalizacji musi cechować szkodliwość dla społeczeństwa ${ }^{4}$, niezależnie od banalności tego stwierdzenia zasygnalizowanej przez L. Gardockiego ${ }^{5}$. Niezbędne jest zatem zidentyfikowanie w rzeczywistości społecznej zachowania odbieranego przez społeczeństwo jako niebezpieczne dla dóbr prawnych, czyli naruszającego je bądź narażającego w stopniu przekraczającym społecznie akceptowalne granice, co do którego istnieje obowiązek ${ }^{6}$ bądź oczekiwanie społeczne kryminalizacji ${ }^{7}$. Podejście takie znajduje wsparcie w stanowisku T. Kaczmarka, który wskazuje, że prawodawca może obejmować normą prawnokarną jedynie takie zachowania społecznie niepożądane, które prowadzą do naruszenia lub narażenia dobra prawnego w stop-

2 Sięgając do znaczenia filozofii jako umiłowania mądrości.

3 Jego autor czynu karalnego jednak nie popełnił, korzystając ostatecznie z przedruku wspomnianych prac zamieszczonego w tomie T. Kaczmarek, Rozważania o przestępstwie i karze. Wybór prac z okresu 40-lecia naukowej twórczości, Warszawa 2006.

4 A. Zoll, Potrzeba racjonalności w reformowaniu prawa karnego, [w:] Teoretyczne i praktyczne problemy współczesnego prawa karnego, red. T. Bojarski et al., Lublin 2011, s. 30; idem [w:] Kodeks karny. Czesść ogólna. Komentarz LEX, t. I, red. A. Zoll, Warszawa 2012, s. 37, 40; W. Wróbel, A. Zoll, Polskie prawo karne. Czesść ogólna, Kraków 2010, s. 301; T. Kaczmarek, Typizacja czynów społecznie niebezpiecznych a jego ustawowe znamiona, [w:] idem, Rozważania o przestępstwie i karze..., s. 107.

5 L. Gardocki, Zagadnienia teorii kryminalizacji, Warszawa 1990, s. 157.

${ }^{6}$ Na temat Kriminalisierungsgebote przykładowo por. C. Roxin, Strafrecht. Allgemeiner Teil, t. 1. Grundlagen. Der Aufbau der Verbrechenslehre, München 2006, s. 43-44; H.-J. Rudolphi [w:] Systematischer Kommentar zum Strafgesetzbuch. Allgemeiner Teil, red. J. Wolter, Köln 1997 (26 Lieferung, Juni 1997), s. 3; W. Hassemer, U. Neumann [w:] Strafgesetzbuch. NomosKommentar, t. 1, red. U. Kindhäuser, U. Neumann, H.-U. Paeffgen, Baden-Baden 2005, s. 91; W. Hassemer [w:] Kommentar zum Strafgesetzbuch. Reihe Alternativkommentare, t. 1, red. K. Seelmann, Neuwied 1990, s. 64; V. Krey, R. Esser, Deutsches Strafrecht. Allgemeiner Teil, Stuttgart. 2011, s. 10 n.; G. Freund [w:] Münchener Kommentar zum Strafgesetzbuch, t. 1, red. B. von Heintschel-Heinegg, München 2011, s. 378; W. Joecks [w:] Münchener Kommentar zum Strafgesetzbuch, t. 1, s. 8; T. Weigend [w:] Strafgesetzbuch. Leipziger Kommentar, t. 1, red. H.W. Laufhütte, R. Rissing-van Saan, K. Tiedemann, Berlin 2007, s. 10; G. Robbers, Strafpflichten aus der Verfassung, [w:] Aufgeklärte Kriminalpolitik oder Kampf gegen das Böse, t. 1. Legitimationen, red. K. Lüderssen, Baden-Baden 1998, s. 147 n.; T. Vogler, Möglichkeiten und Wege einer Entkriminalisierung, ZStW 90, 1978, s. 128 n., z dalszymi odesłaniami.

${ }^{7} \mathrm{Na}$ temat odniesienia społecznego niebezpieczeństwa czynu do teorii kryminalizacji J. Kulesza, Zarys teorii kryminalizacji, Prok. i Pr. 2014, nr 11-12, s. 87 n. 
niu przekraczającym próg społecznej akceptacji bądź tolerancji ${ }^{8}$. Również A. Zoll stwierdza, że „Uzasadniony udziałem w obrocie prawnym stopień zagrożenia dobra prawnego musi być akceptowany lub co najmniej tolerowany"'. O ile poza polem zainteresowania prawa karnego pozostaje stan akceptowanego przez społeczeństwo zagrożenia dóbr prawnych, o tyle potrzeba kryminalizacji może uaktualnić się w przypadkach przekroczenia tolerowanego poziomu zagrożenia, jak również w przypadkach granicznych.

Jak słusznie podnosi T. Kaczmarek — „społeczne niebezpieczeństwo, jako szczególna, metaprawna właściwość czynu, uzasadnia w najobszerniejszym tego słowa znaczeniu (a więc także weryfikuje i racjonalizuje) sens zakazu karnego"10. Aktualność zachowuje również konstatacja A. Krukowskiego, zgodnie z którą „społeczne niebezpieczeństwo stanowi warunek konieczny, uzasadnienie i nieodzowną przesłankę uznania pewnej kategorii typowych zachowań za ustawowo zabronione"11. Rola tego elementu polega na rozpoznaniu zjawiska społecznego ocenianego ujemnie z punktu widzenia pewnych przyjętych w społeczeństwie założeń aksjologicznych ${ }^{12}$. Ustawodawca zakazuje zachowań, które zmierzają do zmiany korzystnego z punktu widzenia jego aksjologicznych założeń, stanu rzeczy w kierunku uznanym przez niego za szkodliwy bądź nakazuje takie zachowania, które mają utrzymać korzystny stan rzeczy albo zmienić w kierunku przez ustawodawcę oczekiwanym ${ }^{13}$. Nie można zatem odmówić pewnej dozy słuszności konstatacji P. Bockelmanna, zgodnie z którą prawo karne nie tylko nie może abstrahować zupełnie od ocen moralnych, lecz jest w nich głęboko zakorzenione ${ }^{14}$.

8 T. Kaczmarek [w:] System Prawa Karnego, t. 3. Nauka o przestęstwie. Zasady odpowiedzialności karnej, red. R. Dębski, Warszawa 2013, s. 281; idem, Paradygmat naruszenia (zagrożenia) dobra prawnego jako aksjologiczna podstawa kryminalizacji, [w:] Między nauka a praktyka prawa karnego. Księga jubileuszowa Profesora Lecha Gardockiego, red. Z. Jędrzejewski et al., Warszawa 2014, s. 148.

9 A. Zoll [w:] Kodeks karny. Czesść ogólna..., s. 48.

10 T. Kaczmarek, O relacji społecznego niebezpieczeństwa czynu do jego bezprawności, [w:] idem, Rozważania o przestępstwie i karze..., s. 89; idem, [w:] System Prawa Karnego, t. 3, s. 285.

11 A. Krukowski, Społeczna treść przestępstwa. Studium z zakresu polityki kryminalnej, Warszawa 1973, s. 146.

12 M. Dąbrowska-Kardas, $O$ dwóch znaczeniach pojęcia społecznego niebezpieczeństwa czynu, CzPKiNP 1997, nr 1, s. 21; por. T. Kaczmarek, Materialna treść przestępstwa jako problem kodyfikacyjny, [w:] idem, Rozważania o przestępstwie i karze..., s. 191; J. Giezek [w:] Prawo karne materialne. Część ogólna i szczególna, red. M. Bojarski, J. Giezek, Z. Sienkiewicz, Warszawa 2006, s. 76; idem [w:] Kodeks karny. Część ogólna, red. J. Giezek, Warszawa 2007, s. 27; R. Zawłocki, Pojęcie i funkcje społecznej szkodliwości czynu w prawie karnym, Warszawa 2007, s. 101 n.; E. Plebanek, Materialne określenie przestępstwa, Warszawa 2009, s. 16.

13 W. Wróbel, A. Zoll, op. cit., s. 40.

14 P. Bockelmann, Bemerkungen über das Verhältnis des Strafrechts zum Moral und zur Psychologie, [w:] Gedächtnisschrift für Gustav Radbruch, red. A. Kaufmann, Göttingen 1968, s. 256-257. 
Jak wskazuje K. Kühl — to właśnie odróżnia prawo karne od innych gałęzi prawa, że zawiera w sobie społeczno-etyczną dezaprobatę czynu sprawcy ${ }^{15}$.

Założenie o konieczności stwierdzenia in abstracto społecznej szkodliwości (niebezpieczeństwa) zachowania mającego zostać poddanym kryminalizacji stanowi dyrektywę kryminalizacyjną dla ustawodawcy ${ }^{16}$. Jak stwierdza M. Dąbrowska-Kardas - „ogranicza swobodę ustawodawcy w decyzjach kryminalizacyjnych poprzez wyznaczenie warunku koniecznego dla rozpoczęcia takiego procesu w postaci zastrzeżenia, iż kryminalizowane mogą być tylko czyny społecznie niebezpieczne"17. Jego decyzja o posłużeniu się instrumentarium prawnokarnym wynika z materialnego charakteru rozstrzygnięcia, mimo braku odwołania do materialnego elementu przestępstwa w art. $1 \S 1$ k.k. Stanowi zatem podstawę dla społecznej szkodliwości czynu jako elementu przestępstwa zarówno w aspekcie abstrakcyjnym (zespołu znamion typu rodzajowego), jak i konkretnym (społecznej szkodliwości wyższej niż znikoma) ${ }^{18}$. Wymóg społecznego niebezpieczeństwa zachowania na gruncie nauki o kryminalizacji jawi się jako niezależny od przyjmowanej, materialnej bądź formalnej, definicji przestępstwa, albowiem w nauce niemieckiej ${ }^{19}$, szwajcarskiej ${ }^{20} \mathrm{i}$ austriackiej ${ }^{21}$ również wymaga się, by zachowanie poddane sankcji cechowała społeczna szkodliwość (Sozialschädlichkeit) ${ }^{22}$, co do-

15 K. Kühl, Fragmentarisches und subsidiäres Strafrecht, [w:] Festschrift für Klaus Tiedemann zum 70. Geburtstag, red. U. Sieber et al., Köln-München 2008, s. 42.

16 A. Krukowski, op. cit., s. 141; M. Królikowski [w:] Kodeks karny. Część ogólna, t. 1, red. M. Królikowski, R. Zawłocki, Warszawa 2011, s. 162.

17 M. Dąbrowska-Kardas, op. cit., s. 29.

18 Por. M. Królikowski, op. cit., s. 164.

19 G. Jakobs, Strafrecht. Allgemeiner Teil. Die Grundlagen und die Zurechnungslehre, Berlin-New York 1991, s. 46; C. Roxin, op. cit., s. 20-21; H.-J. Rudolphi, op. cit., s. 2; W. Hassemer, U. Neumann, op. cit., s. 92; W. Hassemer, op. cit., s. 66; D. Rössner [w:] Gesamtes Strafrecht, red. D. Dölling, G. Duttge, D. Rössner, Baden-Baden 2011, s. 64, 70-71; H. Putzke [w:] Strafgesetzbuch. AnwaltKommentar, red. K. Leipold, M. Tsambikakis, M.A. Zöller, Bonn 2011, s. 1; J. Renzikowski [w:] Strafgesetzbuch. Kommentar, red. J. Renzikowski, H. Matt, München 2013, s. 2; H. Otto, Grundkurs Strafrecht. Allgemeine Strafrechtslehre, Berlin 2004, s. 8; W. Joecks, op. cit., s. 13; P.-A. Albrecht, Entkriminalisierung als Gebot des Rechtsstaats, KritV 1996, nr 4, s. 331; przekrojowo R. Zaczyk, Der Begriff,,Gesellschaftsgefährlichkeit“ im deutschen Strafrecht, [w:] Modernes Strafrecht und ultima-ratio-Prinzip, red. K. Lüderssen, C. Nestler-Tremel, E. Weigend, Frankfurt am Main 1990, s. 113 n.; wreszcie fundamentalnie: K. Amelung, Rechtsgüterschutz und Schutz der Gesellschaft, Frankfurt am Main 1972; krytycznie natomiast, jako o kryterium bezużytecznym dla wyznaczenia granic kryminalizacji W. Frisch, An den Grenzen des Strafrecht, [w:] Beiträge zur Rechtswissenschaft. Festschrift für Walter Stree und Johannes Wessels zum 70. Geburtstag, red. W. Küper, J. Welp, Heidelberg 1993, s. 69 n., szczególnie jednoznacznie na s. 76-77.

20 S. Trechsel, Schweizerisches Strafrecht. Allgemeiner Teil I. Allgemeine Voraussetzungen der Strafbarkeit, Zürich 1998, s. 28; K. Seelmann, Strafrecht. Allgemeiner Teil, Basel 2012, s. 6.

21 O. Triffterer, Österreichisches Strafrecht. Allgemeiner Teil, Wien-New York 1994, s. 14, 45.

22 Poza polem rozważań, również krytycznych, pozostawiono formułowane w doktrynie niemieckiej ograniczenia kryminalizacji bazujące na pojęciach Strafwürdigkeit i Strafbedürftigkeit, najpełniej omówione przez W. Hassemera i U. Neumanna (iidem, op. cit., s. 88 n.), poddane jednak 
wodzi, że na etapie ustanawiania normy prawnokarnej pojęcie to zyskuje charakter autonomiczny (por. poniżej: społeczne niebezpieczeństwo czynu) względem późniejszej społecznej szkodliwości stanowiącej element struktury przestępstwa. Nie neguje to związku między oboma pojęciami.

Konstytucyjnym uzasadnieniem ustanawiania norm prawnokarnych jest, zdaniem Trybunału Konstytucyjnego, art. 5 ustawy zasadniczej ${ }^{23}$. Jak wywodzi on w wyroku z dnia 30 października 2006 r. $^{24}$

Dobór właściwych środków zapobiegania i zwalczania przestępczości jest — w zasadzie — sprawą ustawodawcy [...], on bowiem w pierwszym rzędzie jest odpowiedzialny za realizację wskazanych w art. 5 Konstytucji celów państwa, do których należy także zapewnienie bezpieczeństwa obywateli, obejmującego także ochronę przed zamachami na ich godność, wolność i własność.

Rację ma A. Zoll, stwierdzając, że „W Konstytucji RP z 1997 r. nie mamy wyraźnie wypowiedzianej zasady uzależniającej odpowiedzialność karną od społecznej szkodliwości czynu"25. Wskazuje jednak na zasadę demokratycznego państwa prawnego ${ }^{26}$ oraz wynikającą z niej zasadę proporcjonalności sensu largo jako stanowiące barierę przed kryminalizowaniem zachowań niestanowiących choćby zagrożenia dóbr o wartości społecznej albo stanowiących realizację konstytucyjnie chronionych podstawowych praw i wolności jednostki ${ }^{27}$. W związku z tym, zdaniem K. Buchały i A. Zolla, „wprowadzenie do ustawy karnej typu zachowań, które nie są społecznie niebezpieczne jest sprzeczne z konstytucją"28. Bezpośrednio sytuują wymóg społecznego niebezpieczeństwa czynu w art. 31 ust. 3 Konstytucji również T. Dukiet-Nagórska ${ }^{29}$ oraz W. Wróbel i A. Zoll ${ }^{30}$.

krytyce ze względu na zarzuconą im nieprzydatność przez W. Frischa (idem, op. cit., s. 69 n., zwłaszcza jednoznacznie na s. 77-82).

23 Dla T. Bojarskiego z kolei art. 1 oraz 2 Konstytucji (T. Bojarski, Konstytucyjna ochrona podstawowych wartości humanistycznych a projektowane prawo karne, „Annales UMCS, Sectio G” 44, 1997, s. 26).

${ }^{24}$ P 10/06, OTK-A 2006, nr 9, poz. 128.

25 A. Zoll, Odpowiedzialność karna za czyn niesprowadzajacy zagrożenia dla dobra prawnego w świetle Konstytucji, [w:] Formy stadialne i postacie zjawiskowe popetnienia przestępstwa, red. J. Majewski, Toruń 2007, s. 11; por. podobnie M. Dąbrowska-Kardas, op. cit., s. 28.

26 Odmiennie M. Dąbrowska-Kardas, która zdecydowanie odrzuca dopuszczalność powołania się w tym kontekście na zasadę demokratycznego państwa prawnego (op. cit., s. 28).

27 A. Zoll [w:] Kodeks karny. Część ogólna..., s. 41, 49.

28 K. Buchała, A. Zoll, Polskie prawo karne, Warszawa 1997, s. 222; A. Zoll [w:] Kodeks karny. Część ogólna..., s. 41.

29 T. Dukiet-Nagórska [w:] Prawo karne. Część ogólna, szczególna i wojskowa, red. T. Dukiet-Nagórska, Warszawa 2008, s. 37.

30 W. Wróbel, A. Zoll, op. cit., s. 304; por. również A. Zoll [w:] Kodeks karny. Część ogólna..., s. 41 (tam też w art. 2 Konstytucji); idem, Nowa kodyfikacja karna w świetle Konstytucji, CzPKiNP 1997, nr 2, s. 101-102. 
Jak stwierdza TK w wyroku z dnia 9 października 2001 r. $^{31}$ — za kryminalizacją przemawia brak dostatecznego poziomu ochrony przy użyciu instrumentarium innych gałęzi prawa oraz naruszenie poczucia sprawiedliwości wynikające z braku sformułowania przez ustawodawcę normy prawnokarnej. Trybunał podnosi, że „Obie te wartości wymagają, by czyny o znacznej szkodliwości społecznej spotkały się z reakcją prawnokarną państwa". Zachowanie poddane kryminalizacji ma być „oceniane społecznie jako zło aż tak dotkliwe, że wymaga reakcji prawnokarnej”. Art. 5 Konstytucji oraz jej art. 2 stanowią formalną podstawę realizacji przez państwo obowiązku zapewnienia możliwości uskutecznienia konsty tucyjnie gwarantowanych praw i wolności jednostki — również w aspekcie pozytywnych obowiązków państwa zagwarantowania właściwego poziomu ich ochrony przed ingerencją ze strony innych podmiotów. Wydaje się zatem, że element społecznego niebezpieczeństwa czynu pełni dwojaką rolę. $Z$ jednej strony nakłada na ustawodawcę obowiązek reakcji w przypadku, gdy naruszenie bądź zagrożenie praw i wolności jednostki przekroczy poziom nieakceptowalny w społeczeństwie, w tym wdrożenia ochrony środkami prawnokarnymi odnośnie do szczególnie niebezpiecznych przypadków ingerencji w te dobra, jak również ingerencji w celu ochrony dóbr ogólnospołecznych. W tym wypadku społeczne niebezpieczeństwo kryminalizowanego czynu jest związane z zasadami i wartościami wyrażanymi przez art. 2 i 5 Konstytucji. Z drugiej zaś strony społeczne niebezpieczeństwo czynu stanowi barierę zbyt daleko posuniętej ingerencji ustawodawcy w prawa i wolności jednostki. W tym kontekście społeczne niebezpieczeństwo czynu zawiera się w klauzuli limitacyjnej art. 31 ust. 3 Konstytucji. Realizacja jej elementów ma zagwarantować właściwe zbalansowanie elementu ochrony praw i wolności jednostki albo wartości ogólnospołecznych oraz elementu ingerencji w prawa i wolności jednostki, niezbędnej dla zagwarantowania tej ochrony. Stanowiąca składową klauzuli limitacyjnej, zawartej w art. 31 ust. 3 Konstytucji, zasada proporcjonalności sensu stricto dokonuje ważenia konstytucyjnie gwarantowanych wartości — chronionych i ograniczanych nie tylko pod względem porównania ich wartości z punktu widzenia aksjologii konstytucyjnej, lecz także pod względem zakresu realizacji każdej z nich, uzgodnionego w celu rozwiązania zachodzącej pomiędzy nimi kolizji. Punktem wyjścia badania dopuszczalności ingerencji prawnokarnej jest określenie społecznego niebezpieczeństwa określonego zachowania, w którym mieści się zarówno wskazanie dobra prawnego chronionego przed narażeniem bądź naruszeniem przekraczającym społecznie tolerowalne granice, jak i zakresu ingerencji (w pewnym zakresie) w prawa i wolności jednostki przez określenie treści nakazu bądź zakazu ujętego następnie w opisie typu rodzajowego przestępstwa i obłożonego sankcją karną. W społecznym niebezpieczeństwie czynu zawierają się zatem elementy niezbędne do dokonania wartościowania z punktu

31 SK 8/00, OTK 2001, nr 7, poz. 211. 
widzenia art. 31 ust. 3 Konstytucji i również w ten sposób następuje konstytucyjne uzależnienie odpowiedzialności karnej (kryminalizacji) od społecznego niebezpieczeństwa zachowania obejmowanego sankcją karną.

Nie do końca można zatem zgodzić się z J. Warylewskim, który stwierdza, że w obowiązującym kodeksie karnym zrezygnowano z zasady nullum crimen sine periculo sociali ${ }^{32}$. Należy przyjąć, że nastąpiło przeniesienie tej zasady na wyższy poziom, poziom norm konstytucyjnych, stanowienia norm prawnokarnych. J. Warylewski dostrzega to, jak się zdaje, w innym miejscu, aprobująco powołując pogląd A. Zolla, zgodnie z którym społeczna szkodliwość warunkuje w procesie ustawodawczym tworzenie zakazu karnego ${ }^{33}$. Nie do końca można zgodzić się również z M. Dąbrowską-Kardas ${ }^{34}$, której zdaniem zasada nullum crimen sine periculo sociali nie znajduje umocowania konstytucyjnego ${ }^{35}$, a jej funkcję gwarancyjną przejmują inne zasady konstytucyjne związane z procesem prawotwórczym - w szczególności zasada proporcjonalności sensu largo. Wydaje się, że odnośnie do prawa karnego społeczne niebezpieczeństwo czynu jest niezbędnym elementem testu klauzuli limitacyjnej art. 31 ust. 3 Konstytucji ${ }^{36}$. Nie jest możliwe zwłaszcza przeprowadzenie testu proporcjonalności sensu stricto, bazującego na rozstrzygnięciu konfliktu konstytucyjnie chronionych wartości, polegającego właśnie na naruszeniu bądź zagrożeniu dóbr prawnych indywidualnych bądź zbiorowych kryminalizowanym zachowaniem, które może doprowadzić do wskazania zakresu ingerencji państwa w prawa i wolności jednostki (sprawcy godzenia w dobra prawne), przybierającej postać normy prawnokarnej. Zresztą powołana autorka konstatuje ostatecznie: „wydaje się, że zasada proporcjonalności obejmuje swą treścią zasadę społecznego niebezpieczeństwa czynu"37. Nie można zgodzić się również z R. Zawłockim, którego zdaniem powołanie na zasadę proporcjonalności sensu largo nie jest wystarczającym uzasadnieniem stosowania zasady nullum crimen sine periculo sociali $\mathrm{w}$ ramach tworzenia prawa karnego ${ }^{38}$. Argumenty za istnieniem podstawy w art. 31 ust. 3 Konstytucji przytoczono powyżej. $Z$ tych samych względów nie można również podzielić poglądu L. Gardockiego, który dopuszcza wyjątkowo świadome odstępstwo ustawodawcy od kryterium społecznego niebezpieczeństwa zachowania poddanego kryminalizacji. ${ }^{39} \mathrm{Brak}$

32 J. Warylewski, Społeczna szkodliwość czynu w nowym kodeksie karnym - próba określenia, PS 1998, nr 7-8, s. 5.

33 Ibidem, s. 12 , por. też na s. 8 .

34 M. Dąbrowska-Kardas, op. cit., s. 28-29.

35 Odmawia go tej zasadzie też R. Zawłocki, op. cit., s. 94.

36 Tak również E. Plebanek, op. cit., s. 116; eadem, Karygodność jako element struktury przestępstwa w perspektywie zasady proporcjonalności, [w:] Zasada proporcjonalności w prawie karnym, red. T. Dukiet-Nagórska, Warszawa 2010, s. 136.

37 M. Dąbrowska-Kardas, op. cit., s. 30.

38 R. Zawłocki, op. cit., s. 95.

39 L. Gardocki, Prawo karne, Warszawa 2008, s. 55. 
społecznego niebezpieczeństwa uniemożliwia uzasadnienie ingerencji poprzez kryminalizację w konstytucyjnie chronione prawa i wolności jednostki na podstawie klauzuli art. 31 ust. 3 Konstytucji.

Nie wydaje się jednocześnie błędem powrót do koncepcji A. Krukowskiego ${ }^{40}$, prezentowanej również przez M. Siewierskiego ${ }^{41}$, J. Śliwowskiego ${ }^{42}$ oraz L. Lernella ${ }^{43}$ na gruncie obowiązującego Kodeksu karnego, podtrzymanej przez R. Zawłockiego ${ }^{44}$, by na etapie podejmowania decyzji kryminalizacyjnej posługiwać się pojęciem społecznego niebezpieczeństwa ocenianego zachowania (zgodnie z zasadą $^{45}$ nullum crimen sine lege periculo sociali) ${ }^{46}$. Wydaje się, że upływ wielu już lat od utraty mocy przez Kodeks karny z 1969 r. pozwolił uwolnić się od przyczyn, dla których w obowiązującym Kodeksie pojęcie społecznego niebezpieczeństwa zastąpiono społeczną szkodliwością ${ }^{47}$. Trafnie zauważa J. Giezek, że w polskiej nauce prawa karnego warstwa ideologiczna pojęcia społecznego niebezpieczeństwa czynu nigdy nie zdominowała jego warstwy dogmatycznej ${ }^{48}$, również dzięki

40 A. Krukowski, op. cit., s. 128.

41 M. Siewierski, Kodeks karny i Prawo o wykroczeniach. Komentarz, Warszawa 1965, s. 15.

42 J. Śliwowski, Prawo karne, Warszawa 1979, s. 63, choć odnośnie do tego autora pojęcie społecznego niebezpieczeństwa czynu należy wypełnić nową treścią ze względu na jego silne przezeń zideologizowanie marksistowską nauką prawa karnego (por. na s. 61).

43 L. Lernell, Wykład prawa karnego. Część ogólna, t. I, Warszawa 1969, s. 75.

44 R. Zawłocki, Pojęcie i funkcje społecznej szkodliwości..., s. 97-99, 152-156; idem, O przedmiocie oceny społecznej szkodliwości czynu, [w:] Profesor Marian Cieślak-Osoba. Dzieło. Kontynuacje, red. W. Cieślak, S. Steinborn, Warszawa 2013, s. 571-572; krytycznie A. Grześkowiak [w:] Kodeks karny. Komentarz, red. A. Grześkowiak, K. Wiak, Warszawa 2014, s. 29.

45 M. Dąbrowska-Kardas uznaje społeczne niebezpieczeństwo czynu za regułę, nie zasadę (M. Dąbrowska-Kardas, op. cit., s. 20). Podobnie czyni T. Kaczmarek (T. Kaczmarek, Materialna treść..., s. 187). Odmiennie R. Zawłocki, Pojęcie i funkcje społecznej szkodliwości..., s. 91 n. Na temat różnicy pomiędzy regułą i zasadą por. M. Dąbrowska-Kardas, op. cit., s. 24-25 oraz powołaną tam literaturę.

46 Sceptycznie do takiej propozycji T. Kaczmarek, O próbach reinterpretacji pojęcia społecznej szkodliwości czynu w okresie zmian ustrojowych (na marginesie ksiażki Roberta Zawłockiego), [w:] Węzlowe problemy prawa karnego, kryminologii i polityki kryminalnej. Ksiega pamiatkowa ofiarowana Profesorowi Andrzejowi Markowi, red. V. Konarska-Wrzosek, J. Lachowski, J. Wójcikiewicz, Warszawa 2010, s. 139 n.

$47 \mathrm{Na}$ ten temat A. Zoll, Ogólne zasady odpowiedzialności karnej w projekcie kodeksu karnego, PiP 1990, nr 10, s. 32; idem [w:] Kodeks karny. Część ogólna..., s. 43.

48 J. Giezek, Kodeks karny. Część ogólna. Komentarz, t. I (art. 1-31), Wrocław 2000, s. 18; odmiennie A. Zoll, którego zdaniem pojęcie społecznego niebezpieczeństwa czynu było silnie zabarwione politycznie ze względu na definiowanie go przez pryzmat porządku socjalistycznego (idem [w:] Kodeks karny. Część ogólna ..., s. 43). Rzeczywiście, trudno zapomnieć o takich pracach, jak I. Andrejewa i J. Sawickiego: Społeczne niebezpieczeństwo i bezprawność. Dwa elementy przestęstwa w Polsce Ludowej, Warszawa 1950, tych samych autorów: Istota przestępstwa w Polsce Ludowej. Kilka uwag z zakresu teorii prawa karnego, Warszawa 1949; czy I. Andrejewa, L. Lernella, J. Sawickiego: Prawo karne Polski Ludowej, Warszawa 1950. 
T. Kaczmarkowi, który od początku wiązał element materialny przestępstwa z pojęciem dobra prawnego ${ }^{49}$. Jak słusznie wskazuje J. Waszczyński:

pojęcie społecznego niebezpieczeństwa czynu traci swoją klasową podbudowę i napełnia się nową treścią. Jest nią niebezpieczeństwo, jakie czyn stwarza dla dóbr prawnych uznanych przez legalnie wyłonioną reprezentację narodu za ważne dla normalnego funkcjonowania społeczeństwa $^{50}$.

Pojęcie społecznego niebezpieczeństwa czynu przyjmuje optykę prawodawcy oceniającego na przyszłość zachowania jako mogące stworzyć zagrożenie lub naruszyć dobra prawne. Społeczna szkodliwość odzwierciedla natomiast perspektywę sędziego oceniającego konkretny czyn zabroniony ${ }^{51}$. Tą samą treścią, odrywając je od treści ideologicznych, wypełniają pojęcie społecznego niebezpieczeństwa czynu również K. Buchała i A. Zoll ${ }^{52}$.

Propozycja dyferencjacji terminologicznej zdaje się zyskiwać poparcie w stanowisku A. Zolla, który podkreśla, że

Wynikającą z art. 31 ust. 3 Konstytucji zasadę ograniczającą ustawodawcę w zakresie tworzenia norm karnoprawnych należy wyraźnie odróżniać od zasady wyrażonej w art. 1 $\S 2$ k.k. wprowadzającej wymóg karygodności czynu realizującego znamiona typu czynu zabronionego, a więc czynu karalnego. Pierwsza z nich działa na płaszczyźnie generalnej i abstrakcyjnej, druga — na płaszczyźnie konkretnego indywidualnego czynu ${ }^{53}$.

Za rozróżnieniem takim powinno podążyć również rozróżnienie terminologiczne. Kryminalizacja odnosi się do abstrakcyjnej klasy zachowań identyfikowanych jako zawierające niebezpieczeństwo ziszczenia szkody społecznej, szkody dla dóbr prawnych ${ }^{54}$. Niebezpieczeństwo zawiera w sobie element potencjalności, lecz nie pewności, niedefinitywności ${ }^{55}$, konieczny do spełnienia wymogu racjonalności kryminalizacji tożsamego z realizacją klauzuli limitacyjnej art. 31 ust. 3 Konstytucji. Społeczne niebezpieczeństwo czynu stanowi zatem warunek wystarczający społecznej szkodliwości, jej istotę, zaś pozostałe kryteria wymienione w art. $115 \S 2$ k.k. decydują jedynie o stopniu społecznej szkodliwości ${ }^{56}$.

49 Na co słusznie zwraca uwagę A. Zoll (idem, Przedmowa, [w:] T. Kaczmarek, Rozważania o przestępstwie $i$ karze..., s. 9).

50 J. Waszczyński [w:] Prawo karne w zarysie. Nauka o ustawie karnej i przestępstwie, red. J. Waszczyński, Łódź 1992, s. 93.

51 Por. J. Śliwowski, op. cit., s. 63.

52 K. Buchała, A. Zoll, op. cit., s. 221.

53 A. Zoll, Odpowiedzialność karna za czyn..., s. 19.

54 Por. M. Szerer, Karanie a humanizm, Warszawa 1964, s. 29 n.

55 Ibidem, s. 33; por. podobnie M. Dąbrowska-Kardas, op. cit., s. 23; K. Buchała, Prawo karne materialne, Warszawa 1989, s. 178. Na temat analizy pojęć niebezpieczeństwa i szkody w omawianym kontekście por. A. Krukowski, op. cit., s. 113 n.

56 Por. J. Warylewski, Prawo karne. Część ogólna, Warszawa 2007, s. 312; idem, Społeczna szkodliwość czynu..., s. 10. 
Przeciwko jednoczesnemu posługiwaniu się pojęciami społecznego niebezpieczeństwa i społecznej szkodliwości czynu opowiada się zdecydowanie J. Warylewski. Wyartykułowany przez niego wprost argument odnosi się do obawy o to, że w przypadku pozostawienia pojęcia społecznego niebezpieczeństwa czynu na etapie prawodawczym posługiwanie się nim „uchylałoby się spod wszelkiej kontroli wobec braku instrumentarium dogmatycznego pozwalającego dokonywać ocen w zakresie słuszności, np. penalizacji bądź dekryminalizacji pewnych zachowań"57. Wydaje się jednak, że obawę tę można rozwiać, wskazując na konieczność realizacji wymogów klauzuli limitacyjnej art. 31 ust. 3 Konstytucji, z drugiej zaś strony dokonywaną również przez Trybunał Konstytucyjny kontrolę realizacji przez państwo właściwego poziomu ochrony konstytucyjnie gwarantowanych praw i wolności jednostki. Istnieje zatem instrumentarium, choć nie prawnokarne, pozwalające dokonywać ocen w zakresie słuszności decyzji odnoszących się do prawa penalnego.

Odwołanie do społecznego niebezpieczeństwa zachowania mającego być poddanym kryminalizacji, nawiązującego wprost do późniejszego elementu karalności konkretnego typu czynu zabronionego, stanowi zatem powiązanie tego elementu o charakterze prawnokarnym (konstruującego przestępstwo) z konstytucyjną zasadą proporcjonalności sensu stricto. Jak podkreśla K. Wojtyczek ważenie pozostających w kolizji wartości leżących u podstaw praw i wolności jednostki, mających być chronionymi i mających podlegać ograniczeniu, należy przeprowadzać dla „klasy sytuacji faktycznych, do których odnosi się dana regulacja prawna". Ową sytuację zaś faktyczną, którą należy uwzględnić jako punkt odniesienia, określa przede wszystkim hipoteza badanej normy ${ }^{58}$. Jak z kolei zauważa A. Zoll - określenie przez ustawodawcę typu czynu zabronionego stanowi z punktu widzenia społecznego niebezpieczeństwa kryminalizowanego zachowania konkretyzację, generalizację zaś jeśli idzie o indywidualne czyny ${ }^{59}$. Myśl tę kontynuują K. Buchała i A. Zoll, stwierdzając, że znamiona typu rodzajowego przestępstwa ujmują , ,w formie opisowej elementy konstytutywne dla społecznego niebezpieczeństwa zachowań określonej kategorii’60. Znamiona typu rodzajowego tworzą te cechy określonego zachowania, które przesądzają o jego ujemnym wartościowaniu ${ }^{61}$. Ustawodawca uwzględnia elementy przedmiotowe i podmiotowe zachowania, które ma znaleźć odzwierciedlenie w normie prawnokarnej, ujmując

57 J. Warylewski, Społeczna szkodliwość czynu..., s. 11.

58 K. Wojtyczek, Granice ingerencji ustawodawczej w sfere praw człowieka w Konstytucji $R P$, Kraków 1999, s. 160.

59 A. Zoll [w:] Komentarz do kodeksu karnego. Część ogólna, red. K. Buchała, Warszawa 1994, s. 15.

${ }^{60}$ K. Buchała, A. Zoll, op. cit., s. 221, 223; A. Zoll [w:] Komentarz do kodeksu karnego..., s. 15; idem [w:] Kodeks karny. Część ogólna, s. 41.

${ }^{61}$ K. Buchała, A. Zoll, op. cit., s. 223; por podobnie E. Plebanek, Karygodność jako element struktury..., s. 133-135. 
je w normatywnej przedmiotowo-podmiotowej treści dyspozycji przepisu karnego. Nie wyklucza to jednak uwzględniania również i takich okoliczności, które ostatecznie nie są ujmowane w ustawowym opisie ${ }^{62}$. Trafnie zależność tę ujmuje W. Wolter, stwierdzając, że

chodzi o coś więcej niż o czysto formalne powiązanie dwóch zdań prawdziwych, chodzi również o jakieś powiązanie wewnętrzne, treściowe między tym, co mówi strona merytoryczna a tym co mówi strona formalna [...] strona formalna w jakiś sposób odbija tę ujemną treść społeczną $^{63}$, stanowiącą jej podstawę, określeniem zakazu formalizuje cechę niebezpieczeństwa dla danego układu stosunków społecznych ${ }^{64}$.

Jest to uzasadnione również zależnością między społecznym niebezpieczeństwem zachowania poddanego kryminalizacji a ujęciem zakazu bądź nakazu karnego w zespole znamion typu rodzajowego przestępstwa. Jak stwierdza ponownie - W. Wolter, zasady nullum crimen sine periculo sociali oraz nullum crimen sine lege poenali odzwierciedlają dwie strony tego samego zjawiska społecznego, jakim jest przestępstwo ${ }^{65}$, oczywiście w ujęciu zgeneralizowanym i abstrakcyjnym, a nie indywidualno-konkretnym. Jak wskazuje T. Kaczmarek — „zasada nullum crimen sine lege [...] oznacza, że w procesie tworzenia prawa zakresem penalizacji obejmowane mogą być tylko czyny społecznie szkodliwe [...] w odpowiednio wysokim stopniu, który mógłby usprawiedliwiać i uzasadniać ich karygodność”66. W innym zaś miejscu uzupełnia, iż „czyny ludzkie ocenione z punktu widzenia ich społecznego niebezpieczeństwa dostarczają jedynie substratu dla typizacji czynu, typizacja zaś czynu wydobywa to, co w sposób najbardziej charakterystyczny przesądza tę ujemną ocenę"67. Społeczne niebezpieczeństwo zachowania niepożądanego odnosi się do obiektywnego i rzeczywistego zjawiska, zaś społeczne niebezpieczeństwo typu czynu zabronionego dotyczy jego hipotetycznej projekcji ${ }^{68}$. Również J. Waszczyński wskazuje, że rolą prawidłowej typizacji jest uchwycenie tych cech kryminalizowanego zachowania,

62 R. Zawłocki, O przedmiocie oceny społecznej szkodliwości..., s. 572.

63 Rozumianą jako zamach na „ważne dobro społeczne lub jednostki” (W. Wolter [w:] Kodeks karny z komentarzem, red. I. Andrejew, W. Świda, W. Wolter, Warszawa 1973, s. 22; por. podobnie A. Gubiński, Zasady prawa karnego, Warszawa 1996, s. 33).

64 W. Wolter, Nauka o przestępstwie, Warszawa 1973, s. 15; idem [w:] Wyktad prawa karnego na podstawie kodeksu karnego z 1969 r. Część I. Część ogólna, z. 1. Nauka o ustawie karnej i o przestepstwie, red. K. Buchała, W. Wolter, Kraków 1970, s. 69.

65 W. Wolter [w:] Wyktad prawa karnego..., s. 69-70.

66 T. Kaczmarek, O elementach wyznaczających treść spotecznej szkodliwości czynu zabronionego i jej stopień (ekspozycja problemów spornych), [w:] Teoretyczne i praktyczne problemy..., s. $61-62$.

67 T. Kaczmarek, Typizacja czynów społecznie niebezpiecznych..., s. 109.

68 R. Zawłocki, Pojęcie i funkcje społecznej szkodliwości czynu..., s. 99. 
które decydują o ich społecznie niebezpiecznym charakterze ${ }^{69}$. Zakaz karny „,nakłada się na pewną ujemną treść, wciąga ją w swój kształt" ${ }^{70}$. K. Buchała określa wskazaną powyżej funkcję społecznego niebezpieczeństwa czynu mianem jego funkcji legislacyjnej (jako jednej $\mathrm{z}$ wielu). Wskazuje ona $-\mathrm{z}$ jednej strony - na wymagany stopień społecznego niebezpieczeństwa kryminalizowanego zachowania, który uzasadnić ma sięgnięcie po środki prawnokarne dla ochrony wskazanych dóbr prawnych. $Z$ drugiej strony chodzi o przełożenie „faktów na język ustawy", czyli zapewnienie zgodności społecznej charakterystyki danego rodzaju zachowań z ich prawną charakterystyką ${ }^{71}$. Można dodać, że chodzi o ujęcie, które odzwierciedli taki stopień społecznego niebezpieczeństwa zachowania poddanego kryminalizacji, który jest wystarczająco wysoki, by uzasadnić posłużenie się środkami prawnokarnymi dla ochrony konstytucyjnych praw i wolności przed zachowaniami ujętymi w tworzonym typie rodzajowym. Typizacja odnosi się zatem tylko do takich zachowań, które cechuje stopień społecznego niebezpieczeństwa uzasadniający ich kryminalizację. Zespół znamion typu rodzajowego przestępstwa $\mathrm{z}$ jednej strony opiera się na generalizacji w stosunku do indywidualnych czynów, z drugiej zaś - dokonuje konkretyzacji w stosunku do cechy społecznego niebezpieczeństwa uzasadniającej kryminalizację klasy zachowań. Tworzy on wzorzec, który umożliwia identyfikację zachowania jako należącego bądź nienależącego do kategorii zachowań objętych normą prawnokarną ${ }^{72}$. Ocena prawodawcy odnośnie do rozwiązania sytuacji społecznie niebezpiecznej wyprzedza jego dalszą ocenę związaną z konkretnym brzmieniem normy prawnokarnej, co następuje w przypadku określenia karalności typu rodzajowego przestępstwa. Zatem element karalności jako element pięcioelementowej koncepcji przestępstwa zawiera w sobie efekt uprzedniego rozstrzygnięcia prawodawcy konfliktu wartości konstytucyjnych. Rozstrzygnięcie przez ustawodawcę kolizji wartości na rzecz kryminalizacji określonego zachowania i ingerencji w konstytucyjnie chronione prawa i wolności jednostki znajduje zatem odbicie w karalności jako społecznym niebezpieczeństwie klasy zachowań poddanych ocenie. Wydaje się, że w podobnym kierunku zmierza myśl E. Plebanek, która stwierdza, że „Ocena stopnia społecznej szkodliwości danej kategorii zachowań powinna zatem chronologicznie i logicznie poprzedzać umieszczenie znamion danego typu w ustawie karnej"73.

$\mathrm{W}$ procesie kryminalizacji od ustawodawcy nie wymaga się pełnego, niedopuszczającego wątpliwości dowodu karygodności jakiegoś typu zachowania. Wy-

69 J. Waszczyński, op. cit., s. 97-98; por. podobnie A. Zoll [w:] Komentarz do kodeksu karnego..., s. 15 .

70 W. Wolter et al., Materialne pojęcie przestępstwa i jego konsekwencje w prawie karnym, [w:] Problemy nowego prawa karnego, red. I. Andrejew, Warszawa 1973, s. 23.

71 K. Buchała, op. cit., s. 186.

72 A. Zoll [w:] Komentarz do kodeksu karnego..., s. 15.

73 E. Plebanek, Materialne określenie przestępstwa..., s. 118; eadem, Karygodność jako element struktury..., s. 135. 
magane jest natomiast uprawdopodobnienie istnienia podstaw do kryminalizacji ${ }^{74}$, w tym przede wszystkim właśnie szkodliwości zachowania poddanego kryminalizacji. Jak podkreśla H. Jäger - element społecznej szkodliwości kryminalizowanego zachowania odgrywa szczególną rolę wówczas, gdy podważa się (czego akurat polska doktryna nie czyni) znaczenie pojęcia dobra prawnego jako niedefiniowalnego. Jednocześnie dopuszcza on jedynie właśnie uprawdopodobnienie podstaw kryminalizacji, ponieważ nie zawsze można uzyskać twarde, oparte na faktach dowody istnienia podstaw ustanowienia karalności ${ }^{75}$. Ustawodawca jest jednak w związku z tym ex post zobowiązany do weryfikacji celowości kryminalizacji również pod kątem faktycznego narażania bądź naruszania dóbr prawnych na zagrożenie $^{76}$. W ogóle konieczność nawet uprawdopodobnienia społecznej szkodliwości kryminalizowanego zachowania odrzuca natomiast G. Arzt, nie podając jednak przekonującego uzasadnienia ${ }^{77}$. Podążając $\mathrm{w}$ tym samym kierunku, próbę taką podejmuje E. Hilgendorf, którego zdaniem dopuszczalne jest wprowadzanie kryminalizacji również takich zachowań, odnośnie do których w obecnym stanie wiedzy nie jest pewne, czy stanowią zagrożenia dóbr prawnych, albowiem ustawodawca nie musi udowadniać ani wartości chronionego dobra jako wymagającego ochrony za pomocą instrumentarium prawnokarnego, ani niebezpieczeństwa kryminalizowanego zachowania dla tego dobra prawnego. Uznaje on zatem dyrektywę rozwiązywania sytuacji kolizyjnej in dubio pro libertate za prowadzącą na manowce ${ }^{78}$. Nie bez pewnej dozy racji wskazuje jednak na względność granicy dozwolenia na kontakty seksualne ${ }^{79}$, która w różnych państwach regulowana jest odmiennie, przy czym obserwowalna w ciągu lat tendencja wskazuje na podnoszenie tej granicy, mimo obniżania wieku inicjacji w populacji. Całkowicie odmienne stanowisko, jednak idące nawet dalej niż L. Gardockiego (uprawdopodobnienie podstaw kryminalizacji), zajmuje H. Otto. Jego zdaniem w szczególności pojęcie dobra prawnego służy zmuszeniu ustawodawcy do przedstawienia dowodu konieczności kryminalizacji opartego na racjonalnie weryfikowalnych argumentach. Ma on wykazać nie tylko poddanie ochronie społecznie istotnej wartości, lecz również zgodność własnej oceny z ocena społeczną ${ }^{80}$. Taki sam pogląd prezentują

${ }^{74}$ L. Gardocki, Zagadnienia teorii kryminalizacji, s. 141, 146-148.

75 H. Jäger, Irrationale Kriminalpolitik, [w:] Festschrift für Horst Schüler-Springorum zum 65. Geburtstag, red. P.A. Albrecht et al., Köln 1993, s. 234.

76 W. Wohlers, Verhaltensdelikte: Standard-, Ausnahme- oder Unfall der Strafrechtsdogmatik?, [w:] Grundlagen des Straf- und Strafverfahrensrecht. Festschrift für Knut Amelung zum 70. Geburtstag, red. M. Böse, D. Sternberg-Lieben, Berlin 2009, s. 142.

77 G. Arzt, Probleme der Kriminalisierung und Entkriminalisierung sozialschädlichen Verhaltens, „Kriminalistik” 1981, nr 3, s. 118.

78 E. Hilgendorf [w:] Strafrecht Besonderer Teil, red. G. Arzt et al., Bielefeld 2009, s. 6.

79 Ibidem.

80 H. Otto, op. cit., s. 8. 
R. Maurach i H. Zipf, podkreślając, że społeczna szkodliwość musi być udowodniona w oparciu o empiryczne badania ${ }^{81}$.

Bez wątpienia to na ustawodawcy spoczywa ciężar uzasadnienia wprowadzenia do ustawy określonego typu czynu karalnego ${ }^{82}$. Co więcej, zdaniem K. Buchały i A. Zolla,

potrzeba wprowadzenia karalności zachowania dotychczas niepodlegającego odpowiedzialności karnej wymaga innego uzasadnienia od uzasadnienia utrzymywania nadal karalności jakiegoś zachowania. W pierwszym przypadku to uzasadnienie musi być mocniejsze ${ }^{83}$.

Od ustawodawcy wymaga się wykazania, że wprowadzenie do systemu prawa nowego „typu czynu zabronionego jest uzasadnione zagrożeniem dla dobra prawnego ze strony czynów o określonych znamionach typowych" 84 . Jak słusznie ujmuje to T. Kaczmarek - ustawodawca, tworząc typ rodzajowy przestępstwa, ma na względzie taki czyn, który w przyszłości może wywołać społecznie niepożądane następstwa ze względu na jego potencjalną możliwość spowodowania określonej szkody ${ }^{85}$. Znajduje to odzwierciedlenie w samym językowym ujęciu społecznego niebezpieczeństwa, gdzie owo „niebezpieczeństwo” wskazywać ma właśnie na potencjalną istotną możliwość ujemnych następstw obejmujących również naruszenie dobra prawnego ${ }^{86}$. Bada, czy tego rodzaju czyn może doprowadzić do takich skutków ${ }^{87}$. Z tego względu, choć barometrem społecznego niebezpieczeństwa jest miara potępienia społecznego czynu, dopuszczalna jest również kryminalizacja zachowań, które w ocenach społecznych nie spotykają się z takim potępieniem jak ,tradycyjne” przestępstwa. W takim wypadku to norma prawnokarna, przenikając do świadomości społecznej, stworzy wtórnie kryteria pejoratywnej oceny ${ }^{88}$. W ten sposób nastąpi realizacja wyodrębnianej niekiedy funkcji afirmującej prawa karnego polegającej na kształtowaniu świadomości aksjologicznej i prawnej społeczeństwa ${ }^{89}$. Dlatego trudno zgodzić się z R. Zawłockim, którego zdaniem oparcie

81 R. Maurach, H. Zipf, Strafrecht Allgemeiner Teil. Teilband 1. Grundlehren des Strafrechts und Aufbau der Straftat, Heidelberg 1992, s. 169-170.

82 K. Buchała, A. Zoll, op. cit., s. 15.

${ }^{83}$ Ibidem, s. 127.

84 W. Wróbel, A. Zoll, op. cit., s. 304.

85 T. Kaczmarek, O pojęciu społecznego niebezpieczeństwa czynu (wieloznaczność terminu, próby subiektywizacji niebezpieczeństwa, materialna treść przestępstwa i kryteria jej oceny), [w:] idem, Rozważania o przestępstwie i karze..., s. 63; idem, Typizacja czynów spotecznie niebezpiecznych..., s. 109-110; por. podobnie Z. Sienkiewicz, Społeczne niebezpieczeństwo czynu jako dyrektywa sądowego wymiaru kary (na tle teorii i praktyki sadowej), Wrocław 1977, s. 15, 21; R. Zawłocki, Pojęcie i funkcje społecznej szkodliwości..., s. 98.

86 K. Buchała, op. cit., s. 178.

87 T. Kaczmarek, O pojęciu społecznego niebezpieczeństwa czynu..., s. 63; idem, Typizacja czynów społecznie niebezpiecznych ..., s. 109; idem, O próbach reinterpretacji pojęcia..., s. 139.

88 J. Śliwowski, op. cit., s. 65.

89 Por. W. Cieślak, Prawo karne. Zarys instytucji i naczelne zasady, Warszawa 2010, s. 34-35. 
kryminalizacji na społecznym niebezpieczeństwie czynu wyklucza ją odnośnie do takich zachowań, które nie miały jeszcze miejsca, ponieważ nie tylko norma sankcjonująca zostaje wprowadzona do systemu prawa, lecz także norma sankcjonowana (o ile jest normą prawną). Wskazuje on przede wszystkim na pozakodeksowe przepisy karne mające zabezpieczyć realizację celów ustawy, odnoszące się do potencjalnych i przyszłych zachowań adresatów norm prawnokarnych, które w rzeczywistości jeszcze nie wystąpiły ${ }^{90}$. Zważywszy, że kryminalizacja jest oparta na rozwiązaniu kolizji konstytucyjnie chronionych wartości na podstawie art. 31 ust. 3 Konstytucji, ustawodawca jest uprawniony do oceny potencjalnych zachowań społecznie niebezpiecznych oraz rozwiązania kolizji na rzecz wprowadzenia normy prawnokarnej po to, by chronić wartości, których urzeczywistnieniu służy określona ustawa. Społeczne niebezpieczeństwo nie odnosi się jedynie do zachowań zidentyfikowanych już jako naruszające bądź zagrażające dobrom prawnym, lecz również do takich, które w ocenie ustawodawcy faktycznie wystąpią i będą w takim stopniu społecznie niebezpieczne, by rozważyć ich kryminalizację. Nie ma przesłanek do tego, aby oczekiwać na powstanie zjawiska społecznie niebezpiecznego, by dopiero upewniwszy się, że zaistniało, objąć je sankcją karną. Zwłaszcza w zakresie wywiązywania się ustawodawcy z konstytucyjnego obowiązku zapewnienia wystarczającego poziomu ochrony praw i wolności jednostki pożądane jest uprzednie określenie jej standardów oraz ich realizacja również przy użyciu instrumentarium prawa karnego, a nie oczekiwanie na rozwinięcie się zachowań patologicznych, by dopiero wówczas wprowadzić ochronę prawnokarną. Zastosowanie klauzuli limitacyjnej art. 31 ust. 3 Konstytucji stanowi jednocześnie wystarczającą barierę przez pochopną kryminalizacją.

Ustawodawca dokonuje identyfikacji zachowania jako szkodliwego dla społeczeństwa ze względu na jego godzenie w chronione porządkiem prawnym dobra, co stanowi rację jego kryminalizacji ${ }^{11}$. O. Triffterer przyjmuje, że ustanowienie normy prawnokarnej odpowiada potrzebie społecznej reakcji prawnokarnej wynikającej z zagrożenia pokojowego i uporządkowanego współistnienia w społeczeństwie, będącego efektem naruszenia dobra zbiorowego lub indywidualnego przez sprawcę. Naruszenie to oceniane jest przez społeczeństwo jako tak naganne, że osiągające stopień społecznej szkodliwości uzasadniający ingerencję prawnokarną. O. Triffterer wyprowadza $\mathrm{z}$ tego zasadę ograniczającą zakres kryminalizacji, głoszącą, że norma prawnokarna może obejmować ochroną jedynie szczególnie istotne dobra prawne oraz nie przed każdym naruszeniem, lecz naruszeniem poważnym ${ }^{92}$. Podobnie R. Maurach i H. Zipf definiują społeczną szkodliwość jako cechującą takie zachowanie, które znosi lub w nietolerowalnym stopniu podważa zdolność trwania i funkcjonowania społecznej koegzystencji. Norma prawnokar-

90 R. Zawłocki, Pojęcie i funkcje społecznej szkodliwości..., s. 106-107.

91 A. Zoll [w:] Kodeks karny. Część ogólna..., s. 40.

92 O. Triffterer, op. cit., s. 14, 17. 
na ma prawo wkroczyć tam, gdzie w sposób zniewalający wymaga tego fundamentalna konieczność ochrony zbiorowości lub szczególnie ważnych interesów prawnych jednostki ${ }^{93}$. Podobnie H.-J. Rudolphi stwierdza, że norma prawnokarna może zostać wprowadzona przez ustawodawcę wówczas, gdy jest niezbędna dla ochrony i zabezpieczenia warunków życia społeczeństwa opartego na wolności i odpowiedzialności jednostek ${ }^{94}$. W. Hassemer i U. Neumann wskazują, że kryterium społecznej szkodliwości pozwala na rozgraniczenie prawa karnego i moralności, wymagając uzewnętrznienia naruszenia prawa oraz społecznej manifestacji jego skutków, znaczenia naruszenia „dla nas wszystkich”95. W doktrynie austriackiej wskazuje się poza tym (obok poglądów O. Triffterera), że kryminalizacja powinna być ograniczona do takich zachowań, które naruszają koegzystencję w społeczeństwie w znacznym stopniu ${ }^{96}$. Podobnie w doktrynie szwajcarskiej uznaje się, że uzasadnieniem społecznej szkodliwości jest potencjalne naruszenie spokoju społecznego, co czyni społeczeństwo również potencjalną ofiarą czynu karalnego ${ }^{97}$.

Podobną wykładnię odnaleźć można na gruncie doktryny polskiej. Jak wskazuje R. Zawłocki - decydujące znaczenie dla decyzji ustawodawcy ma treść i waga dobra podlegającego ochronie. Ma ono mieć doniosłą, ponadprzeciętną wagę dla stosunków społecznych ${ }^{98}$. Jednocześnie niezbędne jest, by naruszenie bądź zagrożenie takiego dobra stanowiło zagrożenie całokształtu stosunków społecznych ${ }^{99}$, albowiem ujmując ogólniej: „Społeczne niebezpieczeństwo czynu to pewna ocennie ujęta ujemna właściwość społeczna czynu człowieka"100. Jak trafnie podkreśla T. Kaczmarek — „Społeczne niebezpieczeństwo czynu stanowi obiektywną cechę, z powodu której czyn człowieka przedstawia groźbę dla określonych interesów społecznych, chronionych przez prawo karne" i z tego względu nie jest pożądany dla danej grupy społecznej ${ }^{101}$. Czyn ten stanowi negację pod-

93 R. Maurach, H. Zipf, op. cit., s. 169; por. podobnie H.-H. Jescheck, T. Weigend, Lehrbuch des Strafrechts. Allgemeiner Teil, Berlin 1996, s. 14.

94 H.-J. Rudolphi, op. cit., s. 2.

95 W. Hassemer, U. Neumann, op. cit., s. 92; tak samo sam W. Hassemer wcześniej (idem, op. cit., s. 66).

96 E. Foregger, G. Kodek, E. E. Fabrizy, Strafgesetzbuch. Kurzkommentar, Wien 1997, s. 7-8.

97 K. Seelmann, op. cit., s. 6-7.

98 R. Zawłocki, Pojęcie i funkcje społecznej szkodliwości czynu..., s. 112-113, 120.

$99 \mathrm{Na}$ marginesie warto zauważyć, iż pogląd ten, wyrażony na gruncie innej Konstytucji, innego kodeksu karnego oraz innych realiów społeczno-politycznych jawi się jako pokrewny myśli ujętej w zdaniu L. Lernella z 1969 r. brzmiącym: ,przestępne jest takie zachowanie, które stanowi naruszenie lub zagrożenie dla istoty interesów jednostki (rozpatrywanej w jej kontekście społecznym) lub dla społeczeństwa" (L. Lernell, op. cit., s. 74-75).

100 W. Wolter et al., op. cit., s. 25.

101 T. Kaczmarek, O pojęciu społecznego niebezpieczeństwa czynu..., s. 53, 62, 69; idem, Typizacja czynów społecznie niebezpiecznych..., s. 107. 
stawowych pozytywnych wartości społecznych, a w konsekwencji prowadzi do zakłócenia opartego na nich porządku społecznego (prawidłowych stosunków społecznych) ${ }^{102}$. Cecha ta jest niezależna od świadomości poznającego podmio$\mathrm{tu}^{103}$. Ma ona charakter pierwotny względem ustawowej typizacji zachowania jej poddanego, stanowiąc przesłankę kryminalizacji oraz jej uzasadnienie ${ }^{104}$. Chodzi jednocześnie o takie zachowania, które typowo, powtarzalnie cechuje społeczne niebezpieczeństwo ${ }^{105}$, albowiem bazuje ono na pewnym uogólnieniu, odwołując się do generalnie scharakteryzowanej klasy zachowań ${ }^{106}$. Ustawodawca generalizuje społeczne niebezpieczeństwo kryminalizowanego zachowania, co wynika z jego powtarzalności ${ }^{107}$. Nie można zatem uznać za spełniającą wymogi art. 31 ust. 3 Konstytucji takiej kryminalizacji, przy której ustawodawca ujmie w kształt normy prawnokarnej jedno konkretne zachowanie, które odczytał jako społecznie niebezpieczne. Należy zawsze wykazać powtarzalność zachowań poddanych ocenie - albo faktycznie już zachodzącą, albo potencjalną — jeśli chce się przeciwdziałać zjawisku społecznemu niepożądanemu, jednak dopiero rozwijającemu się. Kryminalizacja nie może natomiast być reakcją na jednostkowe zachowanie — zachowanie indywidualne i konkretne nie może skutkować ustanowieniem normy generalnej i abstrakcyjnej. Słusznie wskazują W. Hassemer i U. Neumann, że zakres karalności musi odpowiadać aktualnym potrzebom społecznym. Zatem jednostkowy przypadek kanibalizmu, który miał miejsce w RFN, nie może stanowić podstawy dla ustanawiania nowego typu rodzajowego przestępstwa ${ }^{108}$, nawet jeśli sprawił trudności w kwalifikacji prawnej ze względu na niemożność oddania całej zwartości bezprawia. Przeciwko takiej kryminalizacji przemawiać ma również, ich zdaniem, wymóg aktualnej przydatności ustanowienia normy, który nie jest spełniony, jeśli mamy do czynienia z zachowaniem budzącym żywe reakcje społeczne, lecz odosobnionym.

102 R. Zawłocki, Pojęcie i funkcje społecznej szkodliwości..., s. 99.

103 T. Kaczmarek, O pojęciu społecznego niebezpieczeństwa czynu, s. 62; idem, Typizacja czynów społecznie niebezpiecznych..., s. 107.

104 M. Dąbrowska-Kardas, op. cit., s. 21-22.

105 Por. A. Zoll, Materialne określenie przestępstwa w projekcie kodeksu karnego, [w:] Problemy kodyfikacji prawa karnego. Księga ku czci profesora Mariana Cieślaka, red. S. Waltoś, Kraków 1993, s. 85; por. T. Kaczmarek, Typizacja czynów społecznie niebezpiecznych..., s. 109.

106 M. Dąbrowska-Kardas, op. cit., s. 23; T. Kaczmarek, O pojęciu społecznego niebezpieczeństwa czynu..., s. 63; idem, Materialna treść przestęstwa..., s. 188; idem, O elementach wyznaczajacych tresść..., s. 62.

107 T. Kaczmarek, O pojęciu społecznego niebezpieczeństwa czynu..., s. 63; idem, Typizacja czynów społecznie niebezpiecznych..., s. 109.

108 W. Hassemer, U. Neumann, op. cit., s. 94; tak samo sam W. Hassemer wcześniej (idem, op. cit., s. 69). 
Nie można jednak zgodzić się z I. Andrejewem ${ }^{109}$, J. Bafią ${ }^{110}$ oraz R. Zawłockim $^{111}$, których zdaniem konieczne jest wykazanie odpowiedniego stopnia powszechności i związanej z nią realności zagrożenia całokształtu stosunków społecznych. Odwołanie do zgeneralizowanej klasy zachowań opiera się na jej abstrakcyjnym ujęciu, podczas gdy wymóg powszechności wskazuje na wymóg empirycznego potwierdzenia powtarzalności zachowań odpowiednio niebezpiecznych. Takie zawężenie kryminalizacji poprzez zawężenie pojęcia społecznego niebezpieczeństwa czynu nie jest uzasadnione, albowiem uniemożliwiałoby istnienie choćby takich typów rodzajowych, jak art. 127 k.k. O stopniu społecznego niebezpieczeństwa czynu rozstrzygającego o możliwości odwołania się do instrumentarium prawnokarnego nie decyduje powszechność niebezpieczeństwa dla dóbr prawnych, lecz ich waga oraz stopień zagrożenia albo naruszenia. Dla stwierdzenia społecznego niebezpieczeństwa nie jest zatem niezbędna częstość zachowań, które mają zostać poddane ocenie — im dalej idąca ingerencja w dobro prawne, tym mniej jest ona niezbędna. Rację ma zatem I. Andrejew, twierdząc, że zachowania szczególnie naganne mogą być kryminalizowane, nawet jeśli nie są rozpowszechnione ${ }^{112}$. W przeciwnym kierunku zmierza refleksja K. Buchały. Wskazuje on, że niektóre zjawiska nie są masowe w społeczeństwie i dlatego nie przedstawiają istotniejszego zagrożenia społecznego niezależnie od ich szkodliwości w jednostkowych przypadkach. Ten brak zagrożenia decyduje o braku kryminalizacji, przy czym posługuje się on ówcześnie (1989 r.) przykładem używania środków odurzających ${ }^{113}$, dziś już bardzo nieaktualnym. Z kolei częstość zachowań nie może przesądzać o odstąpieniu od kryminalizacji, jeśli tylko cechuje je obiektywnie zachodzące społeczne niebezpieczeństwo w stopniu nieakceptowalnym z punktu widzenia szkody społecznej, jaką wyrządza narażenie lub naruszenie dóbr prawnych ${ }^{114}$.

Zdaniem W. Wróbla i A. Zolla istotą społecznej szkodliwości jest zaatakowanie dobra prawnego chronionego przez normę sankcjonowaną oraz naruszenie reguły postępowania z tym dobrem ${ }^{115}$. Można wyrazić wątpliwość, czy faktycznie

109 I. Andrejew, Ustawowe znamiona czynu. Typizacja czynów społecznie niebezpiecznych $i$ kwalifikacja przestepstw, Warszawa 1978, s. 58. Od wymogu rozpowszechnienia przewiduje on odstępstwo jedynie w przypadku czynów o szczególnie znacznej naganności etycznej.

110 J. Bafia, Polskie prawo karne, Warszawa 1989, s. 63.

111 R. Zawłocki, Pojęcie i funkcje społecznej szkodliwości..., s. 114.

112 I. Andrejew, op. cit., s. 58.

113 K. Buchała, Prawo karne materialne, s. 73; idem [w:] Zasady prawa i procesu karnego, red. K. Buchała, S. Waltoś, Warszawa 1975, s. 21.

114 Szerzej na ten temat L. Gardocki, Zagadnienia teorii kryminalizacji..., s. 120-127.

115 W. Wróbel, A. Zoll, op. cit., s. 302; por. podobnie K. Buchała, A. Zoll, op. cit., s. 226; A. Zoll, Znaczenie konstytucyjnej zasady podziału władzy dla prawa karnego materialnego, RPEiS 2006, nr 2, s. 329; tak też, jak się zdaje, Ł. Pohl, skoro naruszenie reguł ostrożności poczytuje za wstępny warunek normowania (Ł. Pohl, Prawo karne. Wykład części ogólnej, Warszawa 2013, s. 26). 
składową społecznego niebezpieczeństwa jest również naruszenie reguły postępowania z dobrem prawnym. Dlatego rację należy przyznać raczej J. Warylewskiemu ${ }^{116}$, który odrzucając pogląd A. Zolla ${ }^{117}$, wskazuje, że istnieje tylko jeden niezbędny warunek uznania zachowania za społecznie szkodliwe (niebezpieczne), w postaci godzenia $\mathrm{w}$ dobro prawne już w postaci narażenia go na niebezpieczeństwo. Przyłącza się on do M. Cieślaka ${ }^{118}$, który warunek ten nazywa obiektywną antyspołecznością czynu. Zatem jedynym warunkiem uznania za społecznie niebezpieczne zachowania mającego zostać poddanym kryminalizacji jest godzenie przez nie w dobro prawne. Obiektywna antyspołeczność owego zachowania będzie służyła do oddzielenia zachowań godzących w dobro prawne w sposób lub w stopniu nieprzekraczającym społecznie tolerowalnych granic od tych, odnośnie do których należy rozważyć objęcie ich sankcją karną. Przekroczenie społecznie tolerowalnej granicy godzenia w dobro prawne pozwoli na uznanie zachowania za obiektywnie antyspołeczne i zadanie pytania o jego kryminalizację. Przekroczenie owej granicy odnośnie do dóbr zbiorowych zaktualizuje społeczny kontekst konieczności zwalczania zachowań w nie godzących. Natomiast w zakresie dóbr indywidualnych przeniesie konflikt o charakterze horyzontalnym praw i wolności jednostek na poziom ogólnospołeczny w związku z koniecznością rozstrzygnięcia owego konfliktu przez prawodawcę, a nie samodzielnie przez jednostki. Nie można jednocześnie przyznać racji M. Dąbrowskiej-Kardas, której zdaniem społeczne niebezpieczeństwo czynu, jako reguła ${ }^{119}$, jest niestopniowalne, a bodźcem kryminalizacji jest stwierdzenie, że zachowanie narusza bądź zagraża dobrom prawnym ${ }^{120}$. Rację należy raczej przyznać J. Waszczyńskiemu, który wskazuje na stopniowalność społecznego niebezpieczeństwa, stwierdzając, że kryminalizacja jest możliwa po przekroczeniu ,pewnego minimalnego progu”"121. Jak wskazuje T. Kaczmarek - ocena społecznego niebezpieczeństwa kryminalizowanego zachowania opiera się na doświadczeniu nabytym w drodze praktyki społecznej ${ }^{122}$. Wskaże ona na stopień prawdopodobieństwa naruszenia chronionych dóbr prawnych, który należy ocenić pod kątem dopuszczalności kryminalizacji. Decyduje ona następnie o rozmiarach karalności ${ }^{123}$. K. Buchała, A. Gubiński i L. Lernell

116 J. Warylewski, Społeczna szkodliwość czynu..., s. 10; idem, Prawo karne, s. 312.

117 Wyrażony ówcześnie w pracy: A. Zoll, Materialne określenie przestępstwa, Prok. i Pr. 1997, nr 2, s. 7.

118 M. Cieślak, Polskie prawo karne. Zarys systemowego ujęcia, Warszawa 1995, s. 135 , $253-254$.

119 Reguła może zostać spełniona, bądź nie, jej realizacja nie podlega natomiast stopniowaniu tak, jak realizacja zasady (M. Dąbrowska-Kardas, op. cit., s. 24-25).

120 Ibidem, s. 20, 23-24.

121 J. Waszczyński, op. cit., s. 13.

122 T. Kaczmarek, O pojęciu społecznego niebezpieczeństwa czynu..., s. 62.

123 A. Marek [w:] Prawo karne. Zagadnienia teorii i praktyki, red. A. Marek, Warszawa 1986, s. 46. 
czynią zasadą kryminalizacji wymóg, zgodnie z którym kryminalizacja może obejmować wyłącznie zachowania szczególnie społecznie niebezpieczne, a zatem istotnie zagrażające dobrom społecznym ${ }^{124}$, który to pogląd znajduje odzwierciedlenie również w doktrynie niemieckiej ${ }^{125}$. V. Krey i R. Esser sytuują ocenę stopnia społecznej szkodliwości uzasadniającego sięgnięcie po narzędzia prawnokarne na etapie oceny proporcjonalności sensu stricto. Argumentują, że sięgnięcie po najsurowszą reakcję systemu prawa związaną z napiętnowaniem sprawcy musi być uzasadnione znaczną społeczną szkodliwością zachowania naruszającego bądź narażającego dobro prawne na zagrożenie ${ }^{126}$. Z kolei A. Wąsek w sposób ogólniejszy stwierdza, że sankcje prawa karnego winny być stosowane tylko do czynów, które osiągają pewien pułap społecznej ujemności ${ }^{127}$.

Wydaje się, że podobnie jak czyni to T. Kaczmarek, określenie niebezpieczeństwa dla dóbr prawnych uzasadniającego wprowadzenie normy prawnokarnej powinno zostać odniesione do kryterium prawdopodobieństwa naruszenia określonych interesów ${ }^{128}$, albowiem przy wykładni pojęcia niebezpieczeństwa nie można abstrahować od jego rozumienia na gruncie prawa karnego, mimo że dokonywana jest ona na etapie stanowienia norm prawnokarnych, a nie ich stosowania. Jeśli określa się niebezpieczeństwo jako prawdopodobieństwo w sensie możliwości, czyli tylko jako niewykluczenie przeciwieństwa, to taka wykładnia jawi się jako niewystarczająca dla rozgraniczenia zachowań, które mogą być poddane procesowi kryminalizacji od tych, które z natury są prawnie irrelewantne. Dlatego T. Kaczmarek słusznie formułuje ocenę, zgodnie z którą zachowaniem społecznie niebezpiecznym uzasadniającym rozważenie kryminalizacji będzie takie, które cechuje znaczne prawdopodobieństwo naruszenia określonych wartości. W ten sposób następuje wydobycie odpowiedniego stopnia nasilenia prawdopodobieństwa, decydujące dopiero o kryminalizacji społecznego niebezpieczeństwa czynu ${ }^{129}$. Racjonalny ustawodawca nie może objąć normą prawnokarną każdego zachowania stwarzającego jakiekolwiek prawdopodobieństwo naruszenia chronionych wartości, albowiem w ten sposób sparaliżowałby życie społeczne ${ }^{130}$.

124 A. Gubiński, op. cit., s. 33; K. Buchała, Prawo karne materialne, s. 178; L. Lernell, op. cit., s. 14.

125 U. Kindhäuser, Strafgesetzbuch. Lehr- und Praxiskommentar, Baden-Baden 2010, s. 44; idem, Strafrecht. Allgemeiner Teil, Baden-Baden 2011, s. 36.

126 V. Krey, R. Esser, op. cit., s. 7.

127 A. Wąsek, Kodeks karny. Komentarz, t. I, Gdańsk 1999, s. 26.

128 T. Kaczmarek, O pojęciu społecznego niebezpieczeństwa czynu..., s. 61, 66-67.

129 Ibidem; T. Kaczmarek, Typizacja czynów spolecznie niebezpiecznych..., s. 107; por. podobnie M. Cieślak, Polskie prawo karne, s. 250; idem, Pojęcie niebezpieczeństwa w prawie karnym, „ZNUJ. Prawo” 1955, nr 1, s. 161.

130 T. Kaczmarek [w:] System Prawa Karnego, t. 3, s. 2780; idem, Paradygmat naruszenia (zagrożenia) dobra prawnego..., s. 147. 
Ustalenie stopnia prawdopodobieństwa uzasadniającego proces kryminalizacji następuje poprzez odwołanie do doświadczenia, obserwacji życia społecznego, a zwłaszcza na podstawie obserwacji częstotliwości występowania pewnych czynów społecznie niebezpiecznych. Kryminalizacją mogą zostać objęte tylko te czyny społecznie niebezpieczne, które cechuje tak wysoki stopień prawdopodobieństwa naruszenia, że z reguły przekształcają się w naruszenie określonych interesów ${ }^{131}$. Umożliwia to kryminalizację również zachowań narażających dobra prawne na zagrożenie, zwłaszcza ujętych później w procesie kryminalizacji w ramy tzw. przestępstw z narażenia abstrakcyjnego.

\section{Criminalization conditioned by a social threat}

\section{Summary}

A human action in order to be criminalized must be deemed socially harmful. In the social realm it is necessary to identify an action perceived as potentially harmful to legally protected values, that is one infringing upon them or threatening them to a degree exceeding socially accepted limits, one that is required or expected to be criminalized. The social threat as a particular characteristic of a human action serves as the broadest justification (hence a verification and a rationalization) of a criminal prohibition. The presumed abstract social harm (a threat) of an action which is to be criminalized serves as the lawmaker's prerequisite for criminalization. Its constitutional foundations lie in the principles of a democratic state and the consecutive principle of proportionality is perceived broadly as a guarantee against the criminalization of actions that do not pose a social threat or ones that exercise individual rights and freedoms granted within the constitution. Penalizing actions that pose no social threat is a violation of the constitution. The notion of a social threat plays therefore a dual role. It obliges the lawmaker to act in cases when the threat to individual rights and freedoms exceeds the socially acceptable level, including the obligation to introduce criminal measures against any particularly harmful infringement of those rights, but also the need to intervene in order to protect the values shared within a society. In the latter case the potential criminalization is originated within the principles and values expressed in Articles 2 and 5 of the Polish constitution. On the other hand, the potential social harm of an action serves as a safeguard against a too far reaching legal interference in individual rights and freedoms. This purpose is expressed in Article 31 para. 3 of the constitution. This limitative clause is to warrant the right balance between the protection of individual rights and freedoms or the protection of shared social values and state interference in those individual rights and freedoms necessary to ensure such protection.

Keywords: social danger of an act, material element of an offense, criminal liability, constitutional scope of criminalization.

131 T. Kaczmarek, O pojęciu społecznego niebezpieczeństwa czynu..., s. 66-67. 